\title{
Napisy dla niesłyszących w Polsce. Historia, problemy, wyzwania
}

\author{
Monika Szczygielska \\ Dostępni.eu/Uniwersytet Warszawski \\ monika@dostepni.eu
}

Streszczenie

$W$ artykule przedstawiam historię rozwoju napisów dla niestyszacych $w$ Polsce i omawiam aktualny stan wiedzy na temat tej formy przekładu audiowizualnego. Prezentuje nastepujace zagadnienia zwiąane z napisami dla niestyszacych: stan prawny, dostępność napisów m.in. w telewizji, kinie, na DVD oraz zasady ich tworzenia na przestrzeni ostatnich 10 lat, obejmujacych lata 2009-19.

Stowa kluczowe: napisy, napisy dla niestyszacych, napisy na żywo, respeaking, dostępność. głusi, stabostyszacy

Abstract

Subtitling for the Deaf and the Hard-of-Hearing in Poland: History, Problems, Challenges

The article presents the history of development of subtitles for the Deaf and hard of hearing in Poland from 2009 to 2019. It also describes the present state of art concerning this type of audiovisual translation. A number of aspects are discussed, including the legal and regulatory context, the availability of access services (TV, cinema, DVD) as well as Polish guidelines on $S D H$

Keywords: subtitling, SDH, live subtitling, respeaking, accessibility, deaf, hard of hearing

\section{Wstęp}

10 lat temu w specjalnym wydaniu czasopisma Przekładaniec, poświęconemu przekładowi audiowizualnemu, Izabela Künstler opublikowała artykuł „Napisy dla niesłyszących - problemy i wyzwania”. Z perspektywy praktyka z Redakcji Napisów dla Niesłyszących TVP opisała stan 
rzeczy w telewizji publicznej, w tym zasady tworzenia napisów dla niesłyszących oraz wskazała wyzwania badawcze i organizacyjne konieczne dla rozwoju napisów. Dekadę później autorka niniejszego artykułu jako praktyk z zespołu Dostępni.eu, który jako pierwszy w Polsce zastosował napisy na żywo metodą respeakingu, podejmuje się opisania zmian w latach 200919 oraz formułuje nowe problemy i wyzwania, jakie stoją obecnie przed twórcami napisów dla niesłyszących.

W artykule przedstawiam historię rozwoju napisów dla niesłyszących w Polsce i omawiam aktualny stan wiedzy na temat tej formy przekładu audiowizualnego. Prezentuję następujące zagadnienia związane z napisami dla niesłyszących: stan prawny, dostępność napisów m.in. w telewizji, kinie, na DVD oraz zasady ich tworzenia.

\section{Napisy dla niesłyszących do 2009 roku}

\subsection{Rzeczywistość prawna 2009}

Dekadę temu Polska ani Unia Europejska nie były stroną Konwencji o prawach osób niepełnosprawnych. W Unii Europejskiej dopiero trwały prace nad dyrektywą o audiowizualnych usługach medialnych. Ustawa o radiofonii i telewizji nie przewidywała żadnych rozwiązań dotyczących dostępności usług audiowizualnych dla osób z niepełnosprawnościami. W polskim porządku prawnym nie istniały także akty prawne dotyczące dostępności cyfrowej. W żadnym dokumencie prawnym nie było zdefiniowanych napisów, ani napisów dla niesłyszących. Telewizja przechodziła $\mathrm{z}$ analogowej w cyfrową, z czym wiązano wielkie nadzieje na zmiany. Przekład audiowizualny definiował swoją nową rolę w kontekście przekładu wewnątrzjęzykowego (por. Szarkowska 2008, Tryuk 2008).

\subsection{Napisy w kinie i w telewizji w 2009 r.}

Napisy dla niesłyszących rozumiane jako zapis ścieżki dźwiękowej, w tym wypowiedzi oraz dźwięków istotnych dla zrozumienia treści dostępne były wyłącznie w dwóch kanałach Telewizji Polskiej (TVP1 i TVP2) oraz na wydanych głównie przez telewizję DVD. Programy z napisami dla niesłyszących ukazują się w TVP od początku 1994 roku. Dziesięć lat temu z napisami dla niesłyszących nadawane były seriale i filmy po wieczornym wydaniu Wiadomości, wybrane filmy przyrodnicze, dokumentalne, teleturnieje, programy informacyjne oraz jeden program publicystyczny. Łącznie codziennie z napisami można było obejrzeć około 8-10\% programów TVP1 i TVP2 (Künstler 2008: 116). Początkowo nadawane były wyłącznie 
wcześniej przygotowane, automatycznie synchronizowane za pomocą kodów czasowych napisy typu pre-recorded (Künstler 2008: 115). Od 2003 roku Teleexpress i od 2007 roku Wiadomości emitowane były z napisami typu semi live, wcześniej przygotowanymi bez kodów czasowych i wypuszczanymi ,ręcznie” przez redaktora w czasie trwania programu.

W kinach i na komercyjnych płytach DVD filmy obcojęzyczne oglądać można było z napisami dialogowymi, przeznaczonymi dla osób słyszących. Napisy dla niesłyszących w kinie dostępne były jedynie podczas pojedynczych pokazów specjalnych dla osób z niepełnosprawnościami wzroku i słuchu, takich jak organizowane w Warszawie od 2008 roku w ramach projektu „Poza Ciszą i Ciemnością,"

\subsection{Teletekst. Napisy a technologia}

W roku 2009 telewizja cyfrowa była w fazie testów. Całkowite przejście z naziemnego sygnału analogowego na cyfrowy nastąpiło w 2013 roku, kiedy to wyłączone zostały ostatnie nadajniki analogowe ${ }^{2}$. W przeszłości, aby obejrzeć program z napisami należało włączyć teletekst $\mathrm{i}$ wybrać odpowiednią stronę (777 w przypadku TVP³). W telewizji cyfrowej napisy włącza się przyciskiem oznaczonym np. TXT na pilocie. W zależności od stacji napisy mogą być dostępne zarówno w formacie tekstowym (z poziomu teletekstu), jak i w standardzie cyfrowym - DVB (ang. Digital Video Broadcasting), albo wyłącznie w DVB. Współcześnie użytkownik dokonuje wyboru w menu ekranowym odbiornika.

\subsection{Wyzwania roku 2009}

Dekadę temu podstawowym problemem badawczym twórców napisów dla niesłyszących było poznanie preferencji ich użytkowników. W swoim tekście, Künstler podkreśla konieczność zmian prawnych. Za wyzwanie uznaje wypracowanie standardów uwzględniających potrzeby użytkowników uczących się czytać i rozwiązań dotyczących programów na żywo. W roku 2019 znane są już preferencje użytkowników napisów telewizyjnych, dwie nowelizacje ustawy o radiofonii i telewizji wprowadziły obowiązek zapewniania napisów w programach telewizyjnych, wydane zostały wytyczne tworzenia napisów dla niesłyszących, a w telewizji przetestowano napisy na żywo. Dziś problemy badawcze i wyzwania są już zupełnie inne.

\footnotetext{
${ }^{1}$ https://dzieciom.pl/film/kino-poza-cisza-i-ciemnoscia, dostęp 30.05.2019.

${ }^{2}$ http://www.krrit.gov.pl/krrit/aktualnosci/archiwum-wiadomosci/news,781, pierwsze-wylaczenie-naziemnejtelewizji-analogowej.html, dostęp 30.05.2019.

${ }^{3}$ http://www.tvp.pl/dostepnosc, dostęp 30.05.2019.
} 


\subsection{Badania o napisach dla niesłyszących przegląd 2009-19}

Po raz pierwszy tematyka napisów dla niesłyszących w Polsce jako część przekładu audiowizualnego pojawiła się na konferencjach naukowych „Intermedia” 2007 Łódź „Conference on Interpreting and Audiovisual Translation” i „Przekład audiowizualny bez barier” w styczniu 2008 roku w Warszawie (Szarkowska 2008: 8-9). Wcześniejsze prace w tej dziedzinie uwzględniały napisy dla niesłyszących jako poboczne metody przekładu audiowizualnego i miały charakter wyłącznie deskryptywny (np. Tomaszkiewicz 2006: 120).

W ostatniej dekadzie w Polsce nastąpił dynamiczny rozwój badań nad napisami dla niesłyszących jak dziedziny przekładu audiowizualnego. Analizowano i badano m.in. preferencje widzów na temat napisów (Szarkowska 2014; Szarkowska i in. 2015) oraz jakość napisów na żywo (Dostępni.eu 2015, 2016). W literaturze przedmiotu opisane zostały zasady tworzenia napisów (Künstler 2009; Szarkowska 2010; Künstler, Butkiewicz 2012; AdamowiczGrzyb 2013; Künstler, Butkiewicz 2019). Badania preferencji wykorzystywane były jako argument podczas nowelizacji prawa. Wnioski z badań oraz powstałe wytyczne przyczyniły się także do opracowania przez Krajową Radę Radiofonii i Telewizji stanowiska w sprawie jakości napisów (2016).

\section{Napisy dla niesłyszących współcześnie}

\subsection{Nowe prawo}

Do roku 2011 polskie prawo nie wymagało od nadawców telewizyjnych zapewniania żadnych napisów. Sytuację zmieniła ustawa z 25 marca 2011 roku o zmianie ustawy o radiofonii i telewizji oraz niektórych innych ustaw ${ }^{4}$. Nadawcy telewizyjni zostali zobowiązani do zapewniania minimum 10\% kwartalnego czasu nadawania audiodeskrypcją, napisami dla niesłyszących i tłumaczeniem migowym. Prawo nie określało procentowego udziału napisów. Artykuł 18a ustawy o radiofonii i telewizji wprowadzał jedynie kwotowy udział łącznych usług dostępnościowych oraz możliwość zwolnienia przez KRRiT nadawców z tego obowiązku m.in. ze względu na możliwości techniczne, sposób rozpowszechniania i specjalizację. Po wejściu w życie ustawy, z inicjatywy KRRiT nadawcy zdecydowali się na samoregulację. W 2013 roku podpisali porozumienie, w którym zostały zdefiniowane napisy dla niesłyszących i napisy na żywo. W dokumencie nie określono „wymiaru czasowego usług dedykowanych dla osób z

\footnotetext{
${ }^{4}$ Dz.U. 2011 nr 85 poz. 459.
} 
dysfunkcją słuchu". Zaznaczono jedynie, że ilość napisów powinna dopełniać określony minimalny poziom audiodeskrypcji i języka migowego do ustawowego $10 \%$ czasu nadawania audycji z ,udogodnieniami”. Napisy dla niesłyszących zostały zdefiniowane jako „napisy w rodzimym języku, będące tekstowym odpowiednikiem mówionych dialogów lub narracji, korespondujące ściśle $\mathrm{z}$ widocznym na ekranie obrazem, zawierające rozróżnienie osób występujących w dialogu (kolorami lub przy pomocy identyfikatorów tekstowych - inicjały, imię bohatera itp.)”. Napisy na żywo zostały zdefiniowane w tym porozumieniu jako ,usługa umożliwiająca osobom $\mathrm{z}$ dysfunkcją narządu słuchu dostęp do treści dźwiękowych towarzyszących obrazowi w czasie prawie rzeczywistym (to jest z niewielkim przesunięciem czasowym), stosowana w audycjach informacyjnych i publicystycznych".

Kolejna ważna nowelizacja ustawy o radiofonii i telewizji miała miejsce 22 marca 2018 roku$^{5}$. Ustawodawca $\mathrm{w}$ art. 18a pkt 2 zobowiązał KRRiT do określenia $\mathrm{w}$ drodze aktu wykonawczego m.in. rodzajów „udogodnień” oraz ich udziału w łącznym czasie nadawania, w zależności od pory emisji, charakteru i rodzaju programu, uwzględniając jednocześnie potrzeby odbiorców, możliwości nadawców oraz rozwój technologii i samych „udogodnień”. Znowelizowana ustawa o radiofonii i telewizji stopniowo podnosi kwartalny czas nadawania audycji z „udogodnieniami” do co najmniej 50\% w 2024 roku. Minimalne progi procentowego kwartalnego czasu nadawania dostępnych audycji w okresie przejściowym wynoszą co najmniej 15\% w 2019 r., 25\% w 2020 r. i 2021 r.; 35\% w 2022 r. i 2023 r. W reżimie ustawy o radiofonii i telewizji z 2011 roku, jak i 2018 roku KRRiT ma prawo ustalania niższego progu i zwalniania nadawców z obowiązku zapewniania dostępności. Dotyczy to głównie nadawców małych i specjalistycznych.

15 listopada KRRiT wydała Rozporządzenie w sprawie udogodnień dla osób niepełnosprawnych z powodu dysfunkcji narządu wzroku i osób niepełnosprawnych z powodu dysfunkcji narządu słuchu w programach telewizyjnych ${ }^{6}$. KRRiT wprowadziła rozróżnienie na trzy rodzaje napisów:

„a) widoczny na ekranie tekst będący odpowiednikiem dialogów i narracji, korespondujący z widocznym na ekranie obrazem, zawierający rozróżnienie osób występujących w dialogu kolorami czcionki lub przy pomocy identyfikatorów tekstowych oraz opisy tekstowe efektów dźwiękowych i tła dźwiękowego,

\footnotetext{
${ }^{5}$ Dz.U. 2018 poz. 915.

${ }^{6}$ Dz.U. 2018 poz. 2261.
} 
b) widoczny na ekranie tekst $\mathrm{w}$ języku polskim zawierający dialogi $\mathrm{i}$ narrację audycji obcojęzycznych, zaliczany do czasu emisji audycji z udogodnieniami dla osób niepełnosprawnych ze współczynnikiem zmniejszającym 0,7 ,

c) tekst w audycjach na żywo, pojawiający się na ekranie z nieznacznym przesunięciem czasowym, będący odzwierciedleniem dialogów lub wypowiedzi”

(Dz.U. 2018 poz. 2261).

Po raz pierwszy rozróżnione zostały w prawie napisy dla niesłyszących i napisy dialogowe odpowiadające thumaczeniu dialogów i narracji z filmów obcojęzycznych. Te drugie podczas monitoringu, jako że nie dostarczają niesłyszącym pełnych informacji, będą liczone z obniżonym współczynnikiem ( 0,7 zamiast 1$)$.

KRRiT ustaliła udział napisów w programach telewizyjnych w docelowym roku 2024 na co najmniej 40\% (przy 7\% audiodeskrypcji i 3\% thumaczenia na język migowy). Po raz pierwszy wprowadziła zróżnicowane wymogi ilości napisów w zależności od gatunku audycji - np. w audycjach informacyjnych i publicystycznych 44\% napisów, a w programach dla dzieci $10 \%$ napisów.

Stopniowy wzrost kwoty programów udostępnianych z napisami zasadniczo powinien wiązać się z koniecznością wykorzystania w szerszym zakresie także napisów na żywo. Udział napisów w różnych typach programów w 2024 roku prezentuje Tabela 1. W latach 2019-23 udział napisów w różnych typach programów będzie proporcjonalnie mniejszy do narzuconych w ustawie kwot. Jednocześnie KRRiT całkowicie zwolniła z obowiązku zapewniania napisów nadawców, których programy emitowane są tylko w internecie.

Programy z napisami mają być nadawane w godzinach 5:00 - 3:00. Przy publikacji w prasie i na stronach internetowych programów telewizyjnych napisy mają być oznaczane symbolem N.

Pierwsze pełne sprawozdanie $\mathrm{z}$ realizacji obowiązków wynikających $\mathrm{z}$ ustawy Przewodniczący KRRiT przedstawi Sejmowi, Senatowi oraz Ministrowi Kultury i Dziedzictwa Narodowego w 2025 roku. Omówi wówczas możliwości zwiększenia poziomu udogodnień dla osób niepełnosprawnych.

Tabela nr 1. Procentowy udział napisów w różnych typach programów w 2024 roku.

(Opracowanie własne, źródło: Rozporządzenia KRRiT 2018) 


\begin{tabular}{|l|l|}
\hline \multicolumn{2}{|c|}{ Udział napisów w poszczególnych typach programów } \\
$\qquad$ w 2024 roku \\
\hline 1. Programy uniwersalne & $40 \%$ \\
\hline 1. Programy wyspecjalizowane > 50\% audycji: & $44 \%$ \\
\hline a/ informacyjnych, publicystycznych & $43 \%$ \\
\hline b/ filmów fabularnych & $42 \%$ \\
\hline c/ społeczno - religijnych & $10 \%$ \\
\hline d/ dla dzieci & $40 \%$ \\
\hline 3. Inne programy wyspecjalizowane & $22 \%$ \\
\hline 4. Programy muzyczne & $21,5 \%$ \\
\hline 5. Programy o zasięgu < 500 tys. mieszkańców & $10 \%$ \\
\hline 6. Programy wyspecjalizowane z udziałem w widowni < 1\%, powyżej 50\% audycji: \\
\hline a/ informacyjnych, publicystycznych & $21 \%$ \\
\hline b/ filmów fabularnych & $20 \%$ \\
\hline c/ społeczno - religijnych & \\
\hline 7. Inne programy wyspecjalizowane z udziałem w widowni < 1\% \\
\hline
\end{tabular}

\subsection{Monitoring. Ile jest napisów w telewizji?}

Nadawcy programów telewizji publicznej oraz programów koncesjonowanych przez KRRiT są zobowiązani do raportowania co kwartał procentowej ilości napisów, audiodeskrypcji i tłumaczeń języka migowego. Na tej podstawie co roku KRRiT przygotowuje zestawienie statystyczne, które ujmuje w sprawozdaniach rocznych.

W 2018 roku KRRiT skontrolowało 108 koncesjonowanych programów telewizyjnych. Audycje z napisami dla niesłyszących stanowiły 15,2\% rocznego czasu nadawania programów telewizyjnych (Sprawozdanie KRRiT 2018, 53). Wśród analizowanych przez KRRiT w 2018 
roku programów, 59 realizowało obowiązki powyżej 15\% dostępności, a 6 programów w przedziale od $47 \%$ do $98 \%$ (Super Polsat $97,7 \%$, TVP HD 73,3\%, TVP Seriale $86,4 \%$, TVR 52,7\%, TVP Fabuła 48,3\%, TVN7 48,1\%, TVP1 47,1\%).

Jesienią 2016 roku podczas konferencji w Berlinie Europejska Unia Nadawców (której TVP jest członkiem) podała, że średnia dla napisów w Europie wynosi 66\% ${ }^{7}$. Każdego roku udział dostępnych programów w telewizji w Polsce rośnie. KRRiT zauważa jednak, że wśród audycji z udogodnieniami istotny udział mają te wielokrotnie powtarzane (Sprawozdanie KRRiT 2017: 31). W sprawozdaniu za 2018 rok KRRiT nie wymienia żadnego programu, który nie spełniałby minimalnego wymogu. W 2017 roku TVP Sport jako jedyny program nie realizował obowiązku na poziomie ustawowego minimum. KRRiT wszczęła wobec nadawcy postępowanie wyjaśniające (Sprawozdanie KRRiT 2017, 31). W 2015 roku z obowiązku nie wywiązało się 5 stacji telewizyjnych. Dwie zostały ukarane przez KRRiT karami pieniężnymi ${ }^{8}$.

Tabela 2. Procentowy udział napisów, audiodeskrypcji i polskiego języka migowego (PJM) w programach telewizyjnych. (Opracowanie własne, źródło: Sprawozdania KRRiT za lata 2012-18).

\begin{tabular}{|l|l|l|l|l|}
\hline & Ogólnie & Napisy & PJM & AD \\
\hline 2018 & $21,5 \%$ & $15,2 \%$ & $2,7 \%$ & $3,6 \$$ \\
\hline 2017 & $19,5 \%$ & $13,6 \%$ & $2,7 \%$ & $3,2 \%$ \\
\hline 2016 & $16,6 \%$ & $12 \%$ & $3 \%$ & $1,6 \%$ \\
\hline 2015 & $17,6 \%$ & \multicolumn{2}{|c|}{$15,2 \%$} & $2,4 \%$ \\
\hline 2014 & $14,2 \%$ & \multicolumn{2}{|c|}{$12,4 \%$} & $1,8 \%$ \\
\hline $2012-13$ & bd & bd & bd & bd \\
\hline
\end{tabular}

Od 2018 roku bieżące statystyki można obserwować na udostępnianej przez KRRiT stronie program.krrit.gov.pl. Ranking obejmuje te stacje, które przesłały dane do KRRiT (nie wszystkie zobowiązane to zrobiły). Algorytm pokazuje 6 programów, w których jest najwięcej napisów lub audiodeskrypcji lub języka migowego w ciągu bieżącej doby albo w godz. 16-22.00, czyli

\footnotetext{
${ }^{7}$ http://saccessibility.pl/ida-zmiany-w-dostepnosci-mediow/, dostęp 30.05.2019

${ }^{8}$ Tamże.
} 
w czasie najlepszej oglądalności. W przedstawionym poniżej, przykładowym rankingu pierwsze miejsce zajął Super Polsat. To program nadawany od 2016 roku, którego nadawca zobowiązał się do emisji 75\% miesięcznego czasu nadawania w godzinach 6:00 - 23:00 audycji dostępnych dla osób z niepełnosprawnościami wzroku i słuchu (Sprawozdanie KRRiT 2017: 31).

Tabela 3. Ranking programów z napisami 29.05.2019, dane z 24h (Źródło: krrit.gov.pl)

\begin{tabular}{|l|l|l|l|l|}
\hline \multicolumn{2}{|l|}{ Ranking programów z napisami (24h) } & N & JM & AD \\
\hline M-ce & Program & $\mathbf{1 8}$ & 1 & 4 \\
\hline 1 & Super Polsat & $\mathbf{1 6}$ & 0 & 1 \\
\hline 2 & TVP1 & $\mathbf{1 4}$ & 0 & 0 \\
\hline 3 & TVP HD & $\mathbf{1 4}$ & 0 & 6 \\
\hline 4 & TVP Seriale & $\mathbf{1 4}$ & 0 & 0 \\
\hline 5 & METRO & $\mathbf{1 3}$ & 1 & 3 \\
\hline 6 & TVP2 & & & \\
\hline
\end{tabular}

\subsection{Napisy w multimediach}

Od 2012 roku obowiązek tworzenia napisów do multimediów zamieszczanych na stronach internetowych zgodnie ze standardem WCAG 2.09 (Web Content Accessibility Guidelines) obowiązuje wszystkie podmioty realizujące zadania publiczne ${ }^{10}$. Nowa ustawa z 2019 roku o dostępności cyfrowej stron internetowych i aplikacji mobilnych podmiotów publicznych ${ }^{11}$ wprowadza dodatkowy okres przejściowy, ale nie zwalnia administracji z tego obowiązku.

\subsection{Napisy w transmisji online}

Zarówno w Unii Europejskiej, jak i Polsce, nie ma prawnego obowiązku stosowania napisów na żywo w transmisji online. Choć przewidywały je międzynarodowe standardy (WCAG 2.0.

\footnotetext{
${ }^{9}$ Obecnie obowiązuje standard WCAG 2.1 .

10 Dz.U. 2012 poz. 526.

${ }^{11}$ Dz.U. 2019 poz. 848.
} 
AA), ze względów technicznych w Polsce zostały pominięte w rozporządzeniu definiującym zakres dostępności stron internetowych podmiotów realizujących zadania publiczne. Prace nad rozporządzeniem trwały $\mathrm{w}$ latach 2010-2011. Wówczas faktycznie nie było w Polsce wystarczająco dopracowanego programu rozpoznawania mowy polskiej, dzięki któremu byłoby to wykonalne. Ze względu na nadmierne obciążenie podmiotów publicznych obowiązek ten pominięto także w dyrektywie o dostępności publicznych stron www i aplikacji mobilnych ${ }^{12}$, a co za tym idzie nie został on przewidziany we wdrażającej dyrektywę ustawie o dostępności cyfrowej stron internetowych i aplikacji mobilnych podmiotów publicznych. Polska jest pewnie jednym z nielicznych krajów, gdzie napisy na żywo od 2018 roku są wymagane w transmisjach online podczas projektów finansowanych z funduszy unijnych ${ }^{13}$.

\subsection{Napisy w kinie i na DVD}

Prawo w Polsce nie reguluje obowiązku nadawania filmów z napisami dla niesłyszących w kinie oraz na DVD. W 2016 roku Polski Instytut Sztuki Filmowej (PISF) po raz pierwszy przeprowadził konkursy $\mathrm{w}$ oparciu o nowy regulamin dotacyjny ${ }^{14}$. Zapis $\mathrm{w}$ regulaminie Programów Operacyjnych PISF brzmiał: „Producent filmu fabularnego i pełnometrażowego filmu animowanego musi wyprodukować ścieżkę $\mathrm{z}$ audiodeskrypcją i napisy dla osób niesłyszących. Audiodeskrypcja i napisy powinny być dołączone do kopii wzorcowej filmu będącej podstawą do produkcji kopii dystrybucyjnych”. Regulamin zobowiązywał do wyprodukowania i załączenia napisów - nie zobowiązywał jednak do ich dystrybucji.

\subsection{Wytyczne. Pierwsze zasady TVP}

Pierwsze wytyczne tworzenia napisów dla niesłyszących wynikały z doświadczeń Redakcji Napisów dla Niesłyszących TVP. Obejmowały one m.in. zasady selekcji informacji, redagowania tekstu i rozmieszczania go na ekranie.

Jak zaznacza Izabela Künstler, miały one charakter subiektywny i nie były weryfikowane badaniami. Jak wspomina ${ }^{15}$ pierwsze napisy w TVP były tworzone "dla niesłyszących posługujących się językiem migowym”. Były bardzo edytowane, skracane, thumaczone na

\footnotetext{
12 Dz.U. L 327/1 z 2.12.2016

${ }^{13}$ Załącznik nr 2 Standardy dostępności dla polityki spójności 2014-2020 do Wytyczne w zakresie realizacji zasady równości szans i niedyskryminacji, w tym dostępności dla osób z niepełnosprawnościami oraz zasady równości szans kobiet i mężczyzn w ramach funduszy unijnych na lata 2014-2020 https://www.funduszeeuropejskie.gov.pl/media/55001/Zalacznik_nr_2_do_Wytycznych_w_zakresie_rownosci_ zatwiedzone_050418.pdf.

${ }^{14}$ http://saccessibility.pl/polskie-kino-w-koncu-bedzie-dostepne/, dostęp 30.05.2019

${ }^{15}$ Rozmowa z Izabelą Künstler.
} 
uproszczony język. Po kilku latach się to zmieniło. Nadal jednak z uwagi na umiejętności czytania osób niesłyszących podstawową kwestią było, co w napisach umieścić, a czego nie. Tworzeniu pierwszych zasad redagowania napisów dla niesłyszących towarzyszyło pytanie: „Czy w dwóch linijkach na ekranie można zmieścić pełny zapis tego, co słychać?”. Wobec braku badań preferencji polskich głuchych i słabosłyszących w sprawie napisów, przy redakcji ówczesnych wytycznych opierano się przede wszystkim na opiniach odbiorców z listów i emaili. Rozważania wokół tego, jaki powinien być cel napisów dziś już raczej nikogo nie zajmują. Dziesięć lat temu uzasadnione mogły wydawać się pytania: „Czy napisy mają umożliwić rozumienie? Oddać wiernie treść wypowiedzi, nawet jeśli odbiór dużej ilości tekstu będzie niełatwy lub wręcz niemożliwy? Pełnić funkcję edukacyjną, czyli pomagać w nauce języka polskiego osobom, dla których pierwszym językiem jest język migowy?”. Izabela Künstler wyrażała wówczas przekonanie, że „spełnienie oczekiwań wszystkich grup widzów niesłyszących jest zadaniem niewykonalnym. Najlepszym rozwiązaniem byłoby jednoczesne przygotowanie różnych wersji napisów" (2008: 118).

W Redakcji Napisów dla Niesłyszących TVP przyjęto zasadę, że wiersz napisów, w którym mieści ok. 38 znaków powinien być widoczny na ekranie przez minimum 3 sekundy. Pierwszy zbiór reguł określił zasady techniczne, z których najważniejsze dotyczyły:

- liczba wersów w napisie (dwa, maksymalnie 3 wersy),

- układu wersów (pierwszy wers krótszy od drugiego),

- kolorów (podstawowy biały, inne: żółty, zielony i niebieski, w teletekście napisy były umieszczane na czarnym pasku, który źle kontrastował z czerwonym i fioletowym),

- identyfikacji mówców (kolorem lub wizytówką),

- zapisu dodatkowych informacji (kapitalikami, w teletekście nie można użyć kursywy)

- ustawienia napisu (na tle osoby mówiącej po lewej, prawej stronie lub na środku; tak by nie zasłaniać innych napisów i plansz w języku polskim)

- zasad dokonywania skrótów.

Wśród specyficznych dla napisów dla niesłyszących zasad redagowania tekstu wymieniano m.in:

- dodatkowe informacje o dźwiękach istotnych dla akcji (pomijamy opis dźwięków wynikających z obrazu), 
- informacje o specyfice mówienia (gwara, intonacja, ironia, jąkanie),

- informacje, których nie pomijamy (nie pomijamy potwierdzeń, zaprzeczeń, okrzyków, zawołań, imion bohaterów),

- unikanie dysonansu poznawczego wśród osób czytających z ust (napisy powinny zawierać kluczowe słowa przy zbliżeniu twarzy),

- zapisywanie tekstów piosenek.

W zakresie leksykalno-gramatycznym rekomendowano zamianę:

- zdań wielokrotnie złożonych na pojedyncze,

- pytań retorycznych w zdania oznajmujące,

- na pytania zdań, których pytający sens zawiera się w intonacji.

Odejście od nadmiernego upraszczania napisów dla niesłyszących pozwoliło stworzyć w TVP zarys zasad. Te pierwsze doświadczenia były podstawą wytycznych tworzonych w przyszłości.

\subsection{Badania preferencji}

Od 2010 roku badania preferencji użytkowników napisów prowadzi Laboratorium Przekładu Audiowizualnego (AVT Lab) w Instytucie Lingwistyki Stosowanej Uniwersytetu Warszawskiego pod kierunkiem dr Agnieszki Szarkowskiej. We wszystkich prowadzonych w Polsce badaniach preferencji użytkowników napisów (Szarkowska 2010, 2014) głusi i słabosłyszący opowiadają się za napisami dosłownymi.

Badania (Szarkowska 2011) wykonane z wykorzystaniem okulografu (ang. eye tracking), polegające na śledzeniu ruchów gałek ocznych, pozwoliły ustalić średni czas spędzony na czytaniu napisów i oglądaniu obrazu, oddzielnie dla napisów: skracanych, standardowych (redagowanych, ale nie upraszczanych) oraz dosłownych. Osoby niesłyszące, przy oglądaniu filmów z napisami dosłownymi, dłużej czytały tekst niż patrzyły na obraz. W badaniu korzystnie wypadły napisy standardowe. W przeciwieństwie do napisów skracanych, pozwoliły widzom śledzić zarówno tekst, jak i akcję. Wypadły też dobrze w testach zrozumienia treści.

Preferencje dotyczące aspektów technicznych napisów badane były w 2014 roku. Badani uznali za najlepsze czcionki do zastosowania w napisach to Verdanę, Arial i Tahomę (Szarkowska, Laskowska 2014: 13). W zdecydowanej większości wybrali zapis treści jak w zdaniu, zamiast drukowanymi literami. Jako najlepsze uznali napisy w dwóch liniach, a jako 
akceptowalne w trzech. Potwierdza to stosowaną obecnie w telewizji konwencję. (Szarkowska, Laskowska 2014: 18).

Badania nie dały jednoznacznej odpowiedzi na pytanie, czy w przypadku napisów dwulinijkowych, górna linia powinna być krótsza niż dolna, by nie zasłaniać obrazu (zob. np. Carroll \& Ivarsson 1998, Künstler \& Butkiewicz 2012).

W kwestii oznaczania dialogów słyszący badani woleli, by wypowiedź każdego z bohaterów zaczynać myślnikiem, jak w napisach do filmów obcojęzycznych. Głusi i słabosłyszący preferowali rezygnację z oznaczania wypowiedzi myślnikiem, jeśli co najmniej jeden z bohaterów jest oznaczony kolorem, co zdaniem autorek badania „może odzwierciedlać ich dotychczasowe przyzwyczajenia związane z oglądaniem napisów w telewizji publicznej” (Szarkowska, Laskowska 2014: 20).

Badanie nie wykazało jednoznacznych preferencji głuchych i słabosłyszących w sprawie opisu dźwięków. Dla respondentów ważne jednak było, by zapis był stosowany konsekwentnie i był czytelny (Szarkowska, Laskowska 2014: 23).

Przy oznaczaniu muzyki badani najczęściej wybierali: słowo MUZYKA lub symbol nutki wraz z opisem jaki muzyka buduje nastrój. Za najlepszą opcję identyfikacji postaci w napisach dla niesłyszących badani uznali kolory, a za najgorszy - rozmieszczenie napisów przy postaciach. Największa grupa badanych ograniczyłaby także liczbę stosowanych kolorów do trzech: żółtego, niebieskiego i zielonego. W przypadku konieczności użycia koloru czwartego wskazywali magentę. Ponad dwie trzecie osób niesłyszących i słabosłyszących uznało, że bohater powinien mieć przypisany kolor przez cały film/serial, a nie od sceny do sceny. Badani widzowie w ok. 90\% akceptują podniesienie napisu w górę, by nie zasłaniać wizytówek przedstawiających osobę mówiącą (Szarkowska, Laskowska 2014).

\subsection{Wytyczne FKBB}

W 2012 roku w ramach działań Fundacji Kultury Bez Barier powstają zasady tworzenia napisów dla niesłyszących. We wprowadzeniu czytamy, że w związku brakiem „społecznego przyzwolenia na zdefiniowanie części odbiorców napisów jako nieposługujących się biegle polskim językiem fonicznym”. Autorki zasad podkreślają, że oczekiwania odbiorców, aby napisy były dosłowne (nawet, jeśli oznacza to nieprzestrzeganie wytycznych tworzenia napisów) stoją $\mathrm{w}$ sprzeczności $\mathrm{z}$ badaniami, które mówią, że $\mathrm{w}$ takiej formie napisy nie umożliwiają większości widzów głuchym pełnego odbioru treści. Przyjmują jednak zasadę, że napisy tworzone są m.in. w celu zadowolenia odbiorców. Godzą się z tym, że najczęściej 
przygotowuje się napisy dla osób biegle posługujących się polskim językiem fonicznym, a napisy uproszczone tworzy się głównie z myślą o dzieciach. Dokument jest podzielony na dwie części. W pierwszej opisane są zasady tworzenia napisów dla niesłyszących biegle posługujących się językiem polskim. Druga część poświęcona jest specyficznym zasadom dla osób uczących się języka polskiego, w tym dzieci. W 2019 roku zasady zostają zaktualizowane.

\subsection{Wytyczne KRRiT}

W 2016 roku KRRiT przyjął Stanowisko w sprawie jakości i sposobu realizacji napisów dla niesłyszących w utworach audiowizualnych. Stanowisko powstało w oparciu o badania z Uniwersytetu Warszawskiego, zasady tworzenia napisów FKBB oraz wytyczne zagraniczne m.in. z Francji i Wielkiej Brytanii. KRRiT promuje wersję napisów „użyteczną dla jak największej liczby odbiorców". W dokumencie czytamy:

„mimo wyraźnej niechęci niektórych środowisk osób niesłyszących wobec stosowania skrótów w napisach do utworów audiowizualnych jest to czasem konieczne w celu zachowania niezbędnej synchronizacji”.

Wytyczne KRRiT są bardzo ogólne. Dotyczą sposobu realizacji napisów: selekcji informacji, czytelności, rozstawienia napisów, czasu wyświetlania i komunikatywności napisów. Nie odnoszą się do badania jakości napisów. Powtarzają zasady tworzenia napisów opisane wcześniej w literaturze przedmiotu (m.in. Künstler 2009; Szarkowska 2010, 2014; Künstler, Butkiewicz i in. 2012). Jedyna nowa wytyczna KRRiT dotyczy napisów w wersji lektorskiej audycji zagranicznych. KRRiT rekomenduje, by zadbać o synchronizację napisów z oryginalnym dźwiękiem, a nie z tłumaczeniem odczytywanym przez lektora. Jednocześnie poleca zapisywanie wtrąceń, których nie tłumaczy się dla odbiorców słyszących, informacji o użytym języku (np. „mówi po włosku”) lub zapis wypowiedzi w języku oryginalnym (np. „buongiorno”) tak, by osobom niesłyszącym znającym język obcy umożliwić równy dostęp do oryginału.

\subsection{Co zmieniło się w napisach przez 10 lat?}

W pierwszych powstałych w TVP wytycznych, a następnie w zasadach FKBB z 2012 roku zakładano, że „najkorzystniejszym rozwiązaniem jest umieszczanie napisów na tle sylwetek bohaterów albo w ich pobliżu”. Miało to ułatwiać identyfikację osób. Badania preferencji z 2014 
roku wykazały, że widzowie sceptycznie podchodzą do tego rozwiązania i preferują rozwiązania znane im z napisów w filmach obcojęzycznych.

Ostatecznie zakończono eksperymenty z czcionkami. Zarówno wytyczne KRRiT jak i zaktualizowane w 2019 roku zasady FKBB rekomendują stosowanie czcionek o prostym kroju i unikanie kursywy.

Ograniczono liczbę rekomendowanych kolorów do żółtego, zielonego, niebieskiego (FKBB 2019) i ewentualnie magenty (KRRiT 2016). Pierwotnie kolor niebieski był zarezerwowany do opisu dźwięków (TVP, FKBB 2012). Współcześnie opisy dźwięków, odgłosów i tła muzycznego są wydzielane z tekstu dialogów nawiasem np. [kwadratowym].

Aktualnie stosowanie WERSALIKÓW zostało ograniczone do identyfikacji postaci i zapisu tekstu tłumaczenia. Kiedyś stosowane były także przy opisie dźwięków (TVP, FKBB 2012).

\subsection{Napisy na żywo}

Napisy na żywo na potrzeby telewizji najczęściej powstają z wykorzystaniem metody respeakingu (Romero Fresco 2018: 200). Jest to technika wykorzystująca oprogramowanie do rozpoznawania i przekładu mowy na tekst (speech-to-text). W Polsce napisy powstają z udziałem respeakera i korektora. Powtórzona przez respeakera wypowiedź, jak rozpoznany i zapisany przez oprogramowanie tekst, trafia do korekty, po której jest przekazywany do oprogramowania do tworzenia napisów telewizyjnych z możliwie jak najkrótszym opóźnieniem (Romero Fresco 2011: 1).

Po raz pierwszy metoda respeakingu w Polsce została zastosowana w 2013 roku podczas konferencji w Sejmie $\mathrm{RP}^{16}$. Od tamtej pory zespół Dostępni.eu tworzył napisy na żywo m.in. podczas konferencji i telewizji. Przy tworzeniu napisów na żywo stosowano programy MagicScribe i Newton Dictate 5. (Szczygielska, Dutka 2019). W 2017 roku zespół Dostępni.eu dla telewizji Polsat tworzył napisy na żywo do programu Dancing with the Stars. Taniec z Gwiazdami ${ }^{17}$.

Telewizja Polska nie podaje do publicznej wiadomości informacji o ilości napisów na żywo w ramówce ani o wykorzystywanym oprogramowaniu i metodach ich tworzenia. Zgodnie z udostępnianym przez stację programem telewizyjnym (stan na maj 2019) z napisami ukazują się następujące programy nadawane na żywo: Teleexpress, Teleexpress Extra, Wiadomości,

\footnotetext{
${ }^{16} \mathrm{https} / / /$ youtu.be/Y6cclCx27rc, dostęp 30.05.2019.

${ }^{17}$ https://youtu.be/DDMhQiakhtY, dostęp 30.05.2019.
} 
Gość Wiadomości oraz Sport, do których część napisów jest potencjalnie tworzona w czasie rzeczywistym. Najprawdopodobniej TVP testowała respeaking podczas Światowych Dni Młodzieży w 2016, a także wieczoru wyborczego w 2018 roku. (Szczygielska, Dutka, 2019).

\section{Podsumowanie}

W perspektywie planowanych zmian legislacyjnych dostępność napisów dla niesłyszących w telewizji powinna w kolejnej dekadzie osiągnąć satysfakcjonującą odbiorców ilość. ${ }^{18}$ Ogólny wzrost dostępności programów telewizyjnych spowoduje znaczne zwiększenie udziału napisów dla niesłyszących, w tym napisów na żywo w telewizji. Powinno to nastąpić wraz ze wzrostem prawnych wymogów ilości napisów w programach nadawanych na żywo m.in. publicystycznych. Po osiągnięciu kryteriów ilościowych, wyzwaniem stanie się rozpoczęcie monitoringu jakości napisów w telewizji, do czego dziś w Polsce nie ma podstaw prawnych. W 2019 roku, pomimo istnienia wytycznych dotyczących tworzenia napisów dla niesłyszących, nikt nie monitoruje jakości napisów, w efekcie czego napisy w różnych programach telewizjach realizowane są według innych konwencji. Wkrótce nowym wyzwaniem będzie też jakość napisów na żywo, w tym napisów międzyjęzykowych. Eksperci i badacze staną przed decyzją: czy adaptować zagraniczne wytyczne w zakresie tworzenia napisów na żywo, czy stworzyć własne. Polska może pójść śladami Wielkiej Brytanii i wykorzystać model NER (skrót od ang. number, edition error and recognition error $)^{19}$, stworzony w celu badania jakości napisów telewizyjnych (Romero-Fresco 2011).

W kinie wyzwaniem będzie wzrost liczby polskich produkcji z napisami dla niesłyszących. Aby to było możliwe konieczne jest m.in. zobowiązanie dystrybutorów do korzystania $\mathrm{z}$ wytworzonych kopii z napisami dla niesłyszących. Kolejne zadanie to wprowadzenie regulacji prawnych dostępności VOD (ang. video-on-demand) oraz zasad ponownego wykorzystania kopii z napisami w serwisach na oferujących wideo na żądanie.

Wraz ze wzrostem zapotrzebowania na napisy dla niesłyszących i napisy na żywo zwiększy się zapotrzebowanie na specjalistów w tej dziedzinie. O ile tworzenia napisów dla niesłyszących można już dziś nauczyć się $\mathrm{w}$ ramach studiów $\mathrm{z}$ tłumaczeń audiowizualnych m.in. na Uniwersytecie Warszawskim, Uniwersytecie Adama Mickiewicza, Uniwersytecie Jagiellońskim, Uniwersytecie SWPS, kurs z wewnątrzjęzykowych napisów na żywo odbywa

\footnotetext{
${ }^{18}$ https://legislacja.rcl.gov.pl/projekt/12319302, dostęp 30.05.2019.

${ }^{19}$ Alternatywa dla modelu WER (z ang. Word Error Rate).
} 
się jedynie na Uniwersytecie Warszawskim. W latach 2018-2020 trwa międzynarodowy projekt ILSA (Interlingual Live Subtitling Access) ${ }^{20}$, który ma na celu opracowanie standardów świadczenia usług napisów na żywo, a także opracowanie materiałów dydaktycznych do kształcenia respeakerów międzyjęzykowych. W Polsce trwają prace nad wpisaniem kwalifikacji specjalisty ds. dostępnych multimediów, który będzie posiadał podstawowe umiejętności w zakresie tworzenia napisów dla niesłyszących, do Zintegrowanego Rejestru Kwalifikacji.

\section{Podziękowania}

Dziękuję dr hab. Agnieszce Szarkowskiej oraz Izabeli Künstler-Zawiszy za wnikliwą lekturę tekstu i cenne uwagi.

\section{Bibliografia}

Adamowicz-Grzyb, Grażyna (2013) Ttumaczenia filmowe w praktyce. Warszawa: Fortima. KRRiT (2016) Stanowisko KRRiT z dnia 26 stycznia 2016 roku w sprawie jakości i sposobu realizacji napisów dla niesłyszacych $w$ utworach audiowizualnych http://www.krrit.gov.pl/dla-mediow-i-analitykow/publikacje/stanowiska/. Data ostatniego dostępu: 30.05.2019.

KRRiT, Sprawozdania Krajowej Rady Radiofonii i Telewizji z działalności w 2012-2018 http://www.krrit.gov.pl/krrit/sprawozdania/. Data ostatniego dostępu: 30.05.2019. Künstler, Izabela (2008) „Napisy dla niesłyszących - problemy i wyzwania”. Przekładaniec 20 (1/2008); 115-124.

Künstler, Izabela, Butkiewicz (2012) „Napisy dla osób niesłyszących i słabosłyszących zasady tworzenia”. Warszawa: Fundacja Kultury bez Barier.

Künstler, Izabela, Urszula Butkiewicz (2019) „Napisy dla osób niesłyszących i słabosłyszących - zasady tworzenia”. Warszawa: Fundacja Kultury bez Barier.

Romero-Fresco, Pablo (2011) Subtitling through Speech Recognition: Respeaking.

Manchester, UK: Kinderhook, NY: St. Jerome Publishing.

Romero-Fresco, Pablo (2012) "Respeaking in Translator Training Curricula. Present and Future Prospects." The Interpreter and Translator Trainer 6(1); 91-112.

${ }^{20}$ http://www.ilsaproject.eu/, dostęp 30.05.2019. 
Romero-Fresco, Pablo (2018) "Reception studies in live and pre-recorded subtitles for the deaf and hard of hearing." [W:] Elena Di Giovanni, Yves Gambier (red.) Reception Studies and Audiovisual Translation. Amsterdam: Benjamins.

Szarkowska, Agnieszka (2008), Przekład audiowizualny w Polsce - perspektywy i wyzwania”. Przektadaniec 20 (1/2008); 8-25.

Szarkowska, Agnieszka, Monika Laskowska (2014) Jakie powinny być napisy? Raport z badania preferencji widzów dotyczących napisów telewizyjnych. Warszawa: Instytut Lingwistyki Stosowanej UW.

Szarkowska, Agnieszka, Jagoda Żbikowska, Izabela Krejtz (2013) "Subtitling for the deaf and hard of hearing in multilingual films." International Journal of Multilingualism 10(3); 292-312.

Szarkowska, Agnieszka (2010) "Accessibility to the media by hearing impaired audiences in Poland: problems, paradoxes, perspectives.” [W:] Jorge Díaz Cintas, Anna Matamala, Josélia Neves (red.) In New Insights into Audiovisual Translation and Media Accessibility. Media for All 2. Amsterdam: Rodopi; 139-158.

Szczygielska, Monika, Łukasz Dutka (2019) „Historia napisów na żywo tworzonych metodą respeakingu w Polsce”. [W:] Krzysztof Hejwowski, Karolina Dębska, Dorota Urbanek (red.) Ttumaczenie wczoraj, dziś i jutro. Warszawa: Instytut Lingwistyki Stosowanej UW; $129-164$.

Tryuk, Małgorzata (2008) „Co to jest thumaczenie audiowizualne”. Przekładaniec 20(1/2008); 26-39.

Tomaszkiewicz, Teresa (2006) Przekład audiowizualny. Warszawa: Wydawnictwo Naukowe PWN.

Tomaszkiewicz, Teresa (2010) „Przekład audiowizualny, werbo-wizualny czy intersemiotyczny: różne wymiary tej samej rzeczywistości?”. Lingwistyka Stosowana 3; 33-44. 